\title{
KONSEPSI KEKUASAAN LEGISLASI PRESIDEN DALAM UNDANG-UNDANG DASAR 1945
}

\author{
Oleh : \\ Daniel Susilo, Mohammad Roesli \\ Universitas Merdeka Surabaya \\ Email : dsshmhum@gmail.com,$\underline{\text { roesli.unmer@gmail.com }}$
}

\begin{abstract}
Penelitian ini adalah untuk menganalisis dan memahami kesesuaian kekuasaan legislatif presiden setelah amandemen UUD 1945 terhadap prinsip-prinsip sistem presidensial. Penelitian hukum ini menggunakan pendekatan statuta, konseptual, komparatif, dan historis. Bahan hukum primer dan sekunder yang digunakan dalam penelitian ini dikumpulkan melalui literatur yang menyelidiki dan menginventarisir bahan hukum dengan dokumen, buku literatur, jurnal hukum, dan undang-undang yang terkait dengan objek penelitian. Bahan hukum yang telah diperoleh dijelaskan dan disajikan secara deskriptif dan analitik dengan menggunakan metode deduktif. Hasil penelitian menunjukkan bahwa kekuasaan legislatif presiden setelah amandemen UUD 1945 tidak sesuai dengan prinsip sistem presidensial pemerintahan secara eksplisit memisahkan kekuasaan eksekutif dan legislatif dalam sistem kekuasaan sebagai implementasi dari gagasan pembatasan negara kekuatan dan prinsip kedaulatan rakyat. Kekuasaan legislatif presiden setelah amandemen UUD 1945 cenderung melemahkan fungsi legislatif, menciptakan ketidakseimbangan antara eksekutif dan legislatif, dan menghambat realisasi legislasi sesuai dengan kehendak rakyat.
\end{abstract}

Keywords: Konsepsi Kekuasaan, UUD 1945, Legislasi

Ikhtiar perubahan terhadap Undang-Undang Dasar Negara Republik Indonesia Tahun 1945, selanjutnya disingkat UUD 1945, dicanangkan di atas prinsip-prinsip negara hukum modern yang bercirikan supremasi hukum, demokrasi, pembatasan kekuasaan, dan perlindungan terhadap Hak Asasi Manusia. Perubahan terhadap hukum dasar tertulis tersebut dilakukan dalam rangka merespons aspirasi masyarakat yang menginginkan suatu format bernegara yang selaras dengan kebutuhan bangsa dan dinamika zaman, tanpa harus meninggalkan Pancasila sebagai filsafat kenegaraan atau mengubah cita-cita nasional yang telah dicanangkan di dalam Pembukaan UUD $1945^{1}$.

Salah satu materi muatan dalam UUD 1945 yang mengalami perubahan mendasar adalah sistem penyelenggaraan kekuasaan negara. Garis perubahan diarahkan pada penegasan prinsip negara hukum, dan sistem konstitusional (constitutional system), penataan kembali

${ }^{1}$ Novita Siswayanti, "REVIEW BUKU: SYARAH KONSTITUSI UUD 1945 DALAM PERSPEKTIF ISLAM,” HUNAFA: Jurnal Studia Islamika, 2013, http://jurnalhunafa.org/index.php/hunafa/article/view/37. 
lembaga-lembaga negara melalui redefinisi fungsi, penghapusan lembaga negara lama, pembentukan beberapa lembaga negara yang baru serta penguatan sistem saling kontrol dan saling mengimbangi (checks and balances system) antarlembaga negara.

Sidang Tahunan MPR Tahun 1999 telah merumuskan beberapa butir kesepakatan dasar dalam rangka perubahan UUD 1945. Salah satu butir kesepakatan dasar tersebut, yaitu mempertahankan sistem presidensial dan menyempurnakan sistem pemerintahan agar betulbetul memenuhi ciri-ciri umum sistem pemerintahan presidensial ${ }^{2}$. Kesepakatan itu bertujuan untuk menciptakan pemerintahan yang stabil dan demokratis dalam sistem ketatanegaraan Negara Kesatuan Republik Indonesia berdasarkan UUD 1945.

Penyempurnaan sistem pemerintahan presidensial tersebut dapat diketahui dari adanya upaya penataan sistem kelembagaan negara termasuk di dalamnya mengenai kekuasaan pemerintahan negara yang menyangkut kedudukan Presiden sebagai kepala pemerintahan eksekutif serta hubungan dan kedudukan Presiden dan Dewan Perwakilan Rakyat dalam pembentukan undang-undang (legislasi).

Masalah kekuasaan legislasi memang menjadi salah satu isu krusial dalam agenda amandemen konstitusi Indonesia pasca reformasi. Sebelum dilakukannya amandemen konstitusi, pengaturan sistem penyelenggaraan kekuasaan negara telah memberi ruang konstitusional bagi Presiden sebagai pemegang kekuasaan eksekutif untuk sekaligus menjalankan kekuasaan legislatif. Kekuasaan eksekutif dan legislatif yang terkonsentrasi di tangan Presiden dapat dilihat sebagai cerminan kuatnya kedudukan Presiden ${ }^{3}$.

Perubahan UUD 1945 telah menegaskan Presiden sebagai pemegang kekuasaan eksekutif (Pasal 4 ayat 1) dan DPR sebagai pemegang kekuasaan membentuk undang-undang (Pasal 20 ayat 1). Meskipun locus kekuasaan pembentukan undang-undang telah dialihkan dari Presiden kepada DPR, namun ternyata Presiden masih memiliki power atau kekuasaan yang cukup besar dalam proses pembentukan undang-undang. Hal ini dapat diketahui dari norma konstitusi yang memberikan hak kepada Presiden untuk mengajukan rancangan undangundang (Pasal 5 ayat 1); ikut membahas rancangan undang-undang bersama DPR dan memberikan persetujuan atas rancangan undang-undang (Pasal 20 ayat 2); menolak untuk memberikan persetujuan atas rancangan undang-undang yang telah dibahas bersama DPR (Pasal 20 ayat 3); dan, mengesahkan rancangan undang-undang yang telah disetujui bersama

\footnotetext{
${ }^{2}$ Hanta Yuda AR, Presidensialisme Setengah Hati (Gramedia Pustaka Utama, 2013).

3 Jimly Asshiddiqie and Ketua Mahkamah Konstitusi RI, "Kedudukan Mahkamah Konstitusi Dalam Struktur Ketatanegaraan Indonesia," Makalah Kuliah Umum di Fakultas Hukum Universitas Sebelas Maret, Surakarta, Kamis 2 (2004).
} 
DPR untuk menjadi undang-undang (Pasal 20 ayat 4). Bagir Manan ${ }^{4}$ menyatakan bahwa kekuasaan Presiden di bidang perundang-undangan memang cukup luas. Presiden turut berbagi kekuasaan dengan badan legislatif dalam membuat undang-undang.

Sistem pemerintahan presidensial merupakan pilihan model dalam membangun dan menata sistem pemerintahan negara Indonesia di era pasca reformasi. Dari sisi teoretik, dalam sistem pemerintahan presidensial terjadi pemisahan tegas antara fungsi cabang kekuasaan lembaga eksekutif dengan kekuasaan legislatif. Presiden adalah kepala negara sekaligus kepala pemerintahan (single executive) yang kedudukannya terpisah dari parlemen. Dalam penggunaan fungsi legislasi terjadi pemisahan antara lembaga legislatif dan pemegang kekuasaan eksekutif ${ }^{5}$.

Berdasarkan uraian diatas maka dirumuskan masalah, yakni apakah pengaturan kekuasaan legislasi Presiden Republik Indonesia sesudah perubahan UUD 1945 telah sesuai dengan prinsip sistem pemerintahan presidensial. Penelitian ini bertujuan untuk menganalisis dan memahami pengaturan kekuasaan legislasi Presiden Republik Indonesia sesudah perubahan UUD 1945 dan kesesuaiannya dengan prinsip sistem pemerintahan presidensial sebagai pilihan sistem pemerintahan negara Republik Indonesia sesudah perubahan UUD 1945.

\section{METODE PENELITIAN}

Penelitian ini dikategorikan sebagai penelitian hukum dengan pertimbangan bahwa penelitian ini bertitik tolak pada analisis terhadap norma konstitusi yang mengatur tentang kekuasaan legislasi Presiden Republik Indonesia sesudah perubahan UUD 1945 dan kesesuaiannya dengan prinsip sistem pemerintahan presidensial. Ada empat jenis pendekatan yang digunakan dalam penelitian ini, yaitu: pendekatan undang-undang (statute approach), pendekatan komparatif (comparative approach), pendekatan konseptual (conceptual approach), dan pendekatan historis (historical approach) ${ }^{6}$.

Teknik pengumpulan bahan hukum primer dan sekunder yang digunakan dalam penelitian ini adalah studi pustaka (library research), yaitu metode pencarian dan inventarisasi bahan hukum primer dan sekunder yang dengan cara menelusuri dokumen, buku-buku literatur, jurnal hukum, dan peraturan perundang-undangan yang terkait dengan obyek penelitian.

\footnotetext{
${ }^{4}$ Bagir Manan, Konvensi Ketatanegaraan (Fh Uii Press, 2006).

5 Saldi Isra, Pergeseran Fungsi Legislasi: Menguatnya Model Legislasi Parlementer Dalam Sistem Presidensial Indonesia (RajaGrafindo Persada, 2010).

${ }^{6}$ Mahmud Marzuki, Penelitian Hukum: Edisi Revisi (Prenada Media, 2017).
} 
Bahan-bahan hukum yang telah diperoleh akan diuraikan dan disajikan secara deskriptif dalam penulisan yang lebih sistematis. Metode interpretasi gramatikal, interpretasi sistematis, interpretasi historis, dan interpretasi telelologis ${ }^{7}$, akan digunakan sebagai alat bantu dalam mengolah dan menganalisis bahan-bahan hukum yang ada. Selanjutnya hasil penelitian akan disimpulkan dengan menggunakan metode deduktif, yakni menarik kesimpulan dari suatu hal yang bersifat umum terhadap permasalahan kongkret yang dihadapi dalam penelitian ini.

\section{HASIL DAN PEMBAHASAN}

\section{Proses Pembentukan Undang-Undang Berdasarkan UUD 1945 Sesudah Perubahan dan Perbandingannya dengan Beberapa Konstitusi}

Dengan bersandar pada doktrin Trias Politica yang dikembangkan oleh Montesquieu, sistem pemerintahan Amerika Serikat dibangun dengan memisahkan secara tegas kekuasaan negara ke dalam tiga cabang, yakni: Legislatif, Eksekutif, dan Yudikatif. Pemisahan yang tegas antara cabang kekuasaan eksekutif dan legislatif merupakan ciri khas sistem pemerintahan presidensial Amerika Serikat.

Pemisahan itu diatur dalam Article I dan Article II Konstitusi Amerika Serikat. Presiden Amerika Serikat adalah pemegang kekuasaan eksekutif tertinggi. Kekuasaan Presiden Amerika Serikat diatur di dalam Article II Section 2 Konstitusi Amerika Serikat yang biasa disebut "The Executive Article". Selain itu, kekuasaan Presiden Amerika Serikat juga tercantum di dalam Article I Section 7. Dari berbagai pengaturan tersebut dapat diketahui bahwasanya Presiden Amerika Serikat tidak hanya memiliki kekuasaan di bidang eksekutif (administrasi, hubungan luar negeri, yustisi, dan sebagainya) namun juga memiliki beberapa kewenangan yang termasuk dalam lingkup kekuasaan legislatif dan yudikatif. Kekuasaan legislatif tertinggi dipegang oleh Kongres Amerika Serikat sebagaimana ditegaskan di dalam Article I Section 1 Konstitusi Amerika Serikat.

Kongres Amerika Serikat memegang fungsi utama dalam pembentukan undang-undang ${ }^{8}$. Menurut Saldi Isra ${ }^{9}$, dalam hal fungsi legislasi, Amerika Serikat merupakan negara pertama yang secara tegas memisahkan fungsi lembaga legislatif dan lembaga eksekutif dalam proses pembentukan undang-undang. Alexander Hamilton dalam the Federalist Paper nomor 24, 26,

${ }^{7}$ Sudikno Mertokusumo, "Penemuan Hukum Sebuah Pengantar,” Yogyakarta: Liberty (1996).

${ }^{8}$ Maruarar Siahaan, "Checks and Balances Dan Judicial Review Dalam Legislasi Di Indonesia," dalam http://www. jimlyschool. com/read/analisis/333/checks-and-balances-dan-judicial-review-dalam-legislasi-diindonesial, diunduh pada 12 (2012).

${ }^{9}$ Isra, Pergeseran Fungsi Legislasi: Menguatnya Model Legislasi Parlementer Dalam Sistem Presidensial Indonesia. 
dan 28, menyatakan pemisahan kekuasaan legislatif dan eksekutif terlihat sebagai bagian upaya mencegah terjadinya pembentukan undang-undang yang merugikan rakyat sehingga kepercayaan rakyat dapat dipertahankan ${ }^{10}$.

Tidak satu pasal pun dalam Konstitusi Amerika Serikat yang menentukan bahwa Presiden mempunyai wewenang untuk mengajukan rancangan undang-undang. Presiden hanya dapat mengusulkan rancangan undang-undang melalui proses yang dikenal dengan istilah Executive Communications, yakni dengan cara menyerahkan draft rancangan undang-undang yang dilengkapi surat pengantar kepada pimpinan Senat dan DPR (Pataniari Siahaan, 2012: 149). Menurut C.F. Strong, dalam praktik sistem presidensial Amerika Serikat, satu-satunya hubungan antara eksekutif dan legislatif adalah melalui laporan presiden (president's message) dan tak seorang pun pejabat kabinet presiden diizinkan turut serta dalam sidang salah satu majelis lembaga legislatif ${ }^{11}$.

Konstitusi Amerika Serikat juga tidak memberi ruang kepada Pemerintah (Presiden atau menteri-menterinya) untuk ikut serta dalam pembahasan rancangan undang-undang. Kehadiran Pemerintah dalam proses ini hanyalah atas permintaan Komisi atau sub-komisi yang diserahi tugas untuk membahas rancangan undang-undang. Mekanisme ini disebut Public Hearings atau semacam rapat dengar pendapat untuk meminta masukan atau testimoni dari pihak-pihak tertentu (lembaga pemerintah, lembaga yudikatif, kalangan ahli, pihak swasta atau kelompok masyarakat) terhadap materi rancangan undang-undang yang sedang dibahas di dalam Komisi atau sub-komisi ${ }^{12}$.

Pemisahan tegas antara cabang kekuasaan legislatif dan eksekutif yang menjadi kerangka dasar sistem pemerintahan presidensial, menempatkan legislatif sepenuhnya mengendalikan agenda dan proses legislasi. Eksekutif memiliki peran yang sangat terbatas dan keterlibatannya dalam proses legislasi hanya terjadi melalui kewenangan menolak atau menerima rancangan undang-undang yang sebelumnya sudah dibahas dan disetujui oleh lembaga legislatif. Penolakan eksekutif melalui hak veto juga masih bisa ditolak kembali oleh legislatif (veto override) dengan dukungan 2/3 suara dari masing-masing kamar yang ada di lembaga legislatif (jika struktur lembaga tersebut menggunakan model bikameral).

Konstitusi Republik Kelima Perancis dirancang untuk membatasi kekuasaan parlemen dan menempatkan eksekutif sebagai sentral kekuasaan negara. Sistem pemerintahan semi-

\footnotetext{
${ }^{10}$ Ibid.

11 Marwan Effendy, Kejaksaan RI: Posisi Dan Fungsinya Dari Perspektif Hukum (Gramedia Pustaka Utama, 2005).

${ }^{12}$ Mochtar Kusumaatmadja and Etty Roesmaryati Agoes, Pengantar Hukum Internasional (Pusat Studi Wawasan Nusantara, Hukum dan Pembangunan bekerjasama dengan Penerbut PT Alumni, 2003).
} 
presidensial Perancis menganut dual executive, Presiden sebagai kepala negara yang berbagi kekuasaan pemerintahan dengan perdana menteri. Sebagaimana dijelaskan Bagir Manan ${ }^{13}$, Presiden Perancis menjalankan kekuasaan riil (menjalankan kekuasaan pemerintahan), tetapi tidak semua kekuasaan pemerintahan ada padanya. Formasi pembagian kekuasaan (power sharing) antara presiden dan perdana menteri menjadi titik penting untuk memahami fungsi legislasi model sistem pemerintahan semi-presidensial. Namun dalam model Perancis kedudukan Presiden memiliki keunikan tersendiri dimana Presiden menjadi titik sentral dengan kewenangan yang besar untuk mengendalikan jalannya pemerintahan termasuk dalam hal pelaksanaan kekuasaan legislasi oleh parlemen ${ }^{14}$.

Karakter fungsi legislasi dalam sistem pemerintahan semi-presidensial, perdana menteri dan setiap anggota parlemen mempunyai hak untuk mengajukan rancangan undangundang. Namun rancangan undang-undang yang diajukan oleh eksekutif harus menjadi prioritas utama karena secara konstitusional pemerintah yang menentukan agenda legislasi di lembaga legislatif ${ }^{15}$. Konstitusi Republik Kelima Perancis didesain untuk memperkuat eksekutif sehingga dominasi eksekutif terhadap legislatif termasuk di dalamnya pada proses legislasi menjadi sesuatu yang tidak bisa dihindari. Pemerintah mengatur agenda parlemen dan menjadi prioritas utama dalam pembentukan undang-undang.

Konstitusi Perancis menegaskan keterlibatan eksekutif dalam proses legislasi yang disebut "shuttle", yakni suatu tahap pembahasan sampai dengan persetujuan rancangan undang-undang ${ }^{16}$. Selama tahap pembicaraan di Majelis Nasional, Pemerintah dapat ikut membahas pada seluruh atau sebagian dari naskah rancangan undang-undang yang sedang dibahas untuk kemudian diperhatikan sebagai masukan dan diadopsi, kecuali parlemen menolaknya. Rancangan undang-undang yang sudah disetujui Majelis Nasional selanjutnya dikirimkan oleh Perdana Menteri kepada Presiden untuk disahkan dan diundangkan sebagaimana mestinya dalam jangka waktu 15 hari sejak rancangan itu disampaikan kepadanya.

Sebelum dilakukannya perubahan UUD 1945, pembentukan undang-undang didasarkan pada Pasal 5 Ayat (1) dan Pasal 20 UUD 1945. Pasal 5 Ayat (1) menegaskan kekuasaan legislasi berada di tangan Presiden dengan persetujuan DPR. Pasal 5 Ayat (1)

\footnotetext{
${ }^{13}$ Manan, Konvensi Ketatanegaraan.

${ }^{14}$ Vicki C Jackson and Mark Tushnet, "Comparative Constitutional Law: Cases and Materials,” 1999.

${ }^{15}$ Isra, Pergeseran Fungsi Legislasi: Menguatnya Model Legislasi Parlementer Dalam Sistem Presidensial Indonesia. 1963).

${ }^{16}$ Sudiman Kartohadiprodjo, Pengantar Tata Hukum Di Indonesia: Hukum Perdata, vol. 1 (Pembangunan,
} 
merupakan salah satu pasal yang termasuk dalam BAB III tentang Kekuasaan Pemerintahan Negara yang juga memuat Pasal 4 Ayat (1) mengenai kedudukan Presiden sebagai pemegang kekuasaan eksekutif. Dengan demikian kekuasaan pembentukan undang-undang sebagaimana dimaksud Pasal 5 Ayat (1) dapat dimaknai berada dalam ruang lingkup kekuasaan pemerintahan dengan Presiden sebagai organnya sebagaimana ditentukan dalam Pasal 4 Ayat (1) UUD 1945 sebelum perubahan.

Hal-ikhwal pembentukan undang-undang juga diatur dalam Pasal 20 Ayat (1) UUD 1945 sebelum perubahan yang menegaskan bahwa pelaksanaan kekuasaan pembentukan undang-undang oleh Presiden mutlak membutuhkan persetujuan DPR. Pada ayat (2) ditegaskan jika rancangan undang-undang tersebut tidak mendapat persetujuan DPR, maka rancangan undang-undang itu tidak boleh diajukan lagi dalam persidangan DPR pada masa itu. Penjelasan UUD 1945 juga menjelaskan bahwa Presiden dan DPR bersama-sama menjalankan “legislative power”. Namun demikian, kekuasaan membentuk undang-undang tetap berada di tangan Presiden karena Pasal 20 dan pasal lainnya di dalam UUD 1945 sesudah perubahan sama sekali tidak menyebutkan secara eksplisit bahwa DPR memegang kekuasaan membentuk undang-undang.

Konstitusi RIS menempatkan tiga lembaga sekaligus sebagai subyek pemegang kekuasaan membentuk undang-undang, yakni Pemerintah, DPR dan Senat. Hal ikhwal tentang perundang-undangan diatur dalam Pasal 127-143 Konstitusi RIS. Eksekutif terlibat aktif dalam proses pembentukan undang-undang sejak dari tahap pengajuan, pembahasan, persetujuan dan pengesahan. Tingkat ketergantungan eksekutif atas dukungan parlemen dan tidak adanya pemisahan yang tegas antara cabang eksekutif dengan cabang legislatif menjadi bagian penting dalam menjelaskan fungsi legislasi dalam sistem pemerintahan. (Isra, 2010:79). Prinsip yang berlaku adalah supremasi parlemen yang menempatkan parlemen sebagai pemegang kekuasaan legislatif. Namun, karena tidak adanya pemisahan yang tegas dan adanya rangkap kedudukan itu maka eksekutif juga ikut serta dalam proses pembentukan undang-undang bersama legislatif.

\section{Kekuasaan Legislasi Presiden Sesudah Perubahan UUD 1945 dalam Kerangka Sistem Pemerintahan Presidensial}

Dalam sistem kekuasaan negara berdasarkan sistem presidensial, Prinsip supremasi konstitusi menempatkan UUD 1945 sebagai tumpuan sistem kedaulatan rakyat dan sebagai satu-satunya hukum dasar tertulis dan dasar legalitas dalam menjalankan kedaulatan rakyat. Ketentuan ini sekaligus mengandung makna bahwa negara Indonesia adalah negara demokrasi 
yang dibatasi oleh hukum yang dibuat atas dasar kehendak rakyat (democratische rechtstaat; constitutional democracy state). Pengaturan dan pembagian pelaksanaan kedaulatan rakyat itu dieksekusi langsung oleh rakyat sendiri (misalnya melalui pemilihan umum) dan oleh lembagalembaga negara yang diserahi tugas menyelenggarakan kekuasaan negara menurut kedudukan, fungsi dan wewenangnya masing-masing sebagaimana ditentukan oleh UUD 1945. Dengan ditegaskannya locus kedaulatan di tangan rakyat maka setiap lembaga negara yang mengemban fungsi-fungsi negara dan pemerintah (di luar kekuasaan yudikatif) adalah pelaksana kedaulatan rakyat dan harus tunduk dan bertanggung jawab kepada rakyat ${ }^{17}$.

Pengalihan kekuasaan pembentukan undang-undang dari Presiden kepada DPR merupakan salah satu bagian dari upaya menata kembali kedudukan dan hubungan eksekutif dan legislatif dalam penyelenggaraan pemerintahan negara. Pengalihan atau pergeseran kekuasaan legislasi kepada DPR merupakan ciri sistem presidensial sekaligus wujud pelaksanaan kedaulatan rakyat dan pembatasan kekuasaan. Kewenangan Presiden di bidang legislasi sebagaimana dikonstruksikan dalam UUD 1945 sesudah perubahan telah mendistorsi prinsip pemisahan kekuasaan dan mengakibatkan ketidakseimbangan kedudukan Presiden dan DPR dalam pembentukan undang-undang. Ketidakseimbangan akibat kewenangan legislasi Presiden yang cukup besar dapat menciptakan dominasi Presiden dalam pembentukan undangundang dan berpotensi memicu tindakan penyalahgunaan kekuasaan oleh Presiden

Kekuasaan legislasi Presiden sesudah perubahan UUD 1945 tidak tepat jika diletakkan dalam kerangka sistem pemerintahan presidensial. Bahkan kekuasaan legislasi Presiden sesudah perubahan UUD 1945 itu tidak dapat dipahami dari sudut pandang sistem pemerintahan manapun yang berkembang

di era demokrasi modern yang menekankan kekuasaan membentuk undang-undang ada pada lembaga perwakilan rakyat. Sistem pemerintahan presidensial menempatkan legislatif sebagai lembaga yang mempunyai kekuasaan yang lebih luas dibandingkan eksekutif. Ikut campurnya eksekutif dalam proses legislasi tidak sejalan dengan hakikat legislasi dan kedudukan lembaga legislatif dalam sistem pemerintahan presidensial yang menganut pemisahan secara tegas kedudukan dan fungsi cabang kekuasaan eksekutif dan legislatif dalam penyelenggaraan kekuasaan negara.

Hak inisiatif Presiden sebagaimana ditegaskan dalam Pasal 5 ayat (1) UUD 1945 merupakan hal yang tidak lazim dalam praktek legislasi pada sistem pemerintahan presidensial. Pengajuan rancangan undang-undang merupakan tugas rutin anggota DPR sebagai wujud pelaksanaan fungsi legislasi DPR. Pengajuan rancangan undang-undang oleh eksekutif

\footnotetext{
${ }^{17}$ Manan, Konvensi Ketatanegaraan.
} 
merupakan ciri khas sistem parlementer karena dalam sistem parlementer eksekutif adalah bagian dari legislatif sebagai akibat dari tidak adanya pemisahan secara tegas cabang eksekutif dan legislatif.

Hak inisiatif Presiden sebagaimana diatur dalam Pasal 5 ayat (1) UUD 1945 mengaburkan kedudukan Presiden sebagai pemegang kekuasaan eksekutif dan DPR sebagai pemegang kekuasaan legislatif. Pemisahan kekuasaan sebagai prinsip sistem presidensial tidak terjabarkan dengan sempurna. Pengajuan rancangan undang-undang oleh Presiden seharusnya dapat dilakukan oleh anggota DPR yang berasal dari partai politik Presiden.

Adanya hak Presiden untuk mengajukan rancangan undang-undang secara tidak langsung berpengaruh pada kinerja DPR dan para anggotanya dalam proses legislasi. Anggota DPR lebih banyak bersikap pasif dan tidak kreatif dalam proses legislasi. Padahal keaktifan anggota DPR dalam proses legislasi termasuk dalam mengajukan rancangan undang-undang menjadi ukuran perwujudan tanggung jawab anggota DPR terhadap amanat kedaulatan rakyat yang dimandatkan oleh rakyat melalui pemilihan umum.

Hak inisiatif Presiden memudahkan Presiden untuk memaksakan agenda politiknya untuk dijelmakan dalam bentuk undang-undang. Undang-Undang No. 12/2011 menegaskan bahwa apabila Presiden dan DPR mengajukan rancangan undang-undang yang mengatur materi yang sama maka rancangan undang-undang-undang yang berasal dari DPR lebih diutamakan untuk dibahas. Ketentuan UU No. 12/2011 tersebut menjadi tidak bermakna karena pada prakteknya Presiden selaku eksekutif yang lebih dominan berinisiatif mengajukan rancangan undang-undang dan DPR lebih bersikap pasif. Apalagi jika mayoritas kursi DPR dikuasai oleh partai pemerintah atau koalisi partai pendukung pemerintah maka akan lebih memudahkan Presiden untuk memaksakan agenda politiknya untuk diwujudkan ke dalam undang-undang.

Kombinasi dominasi eksekutif dan rendahnya kualitas dan sikap pasif anggota DPR dalam pengajuan rancangan undang-undang, serta konfigurasi peta kekuatan politik di DPR, dapat dengan mudah dibaca sebagai suatu dinamika yang mengkhawatirkan jika ternyata rancangan undang-undang yang diajukan eksekutif ternyata tidak sejalan dengan apa yang dikehendaki rakyat. Pada kondisi seperti ini, peran strategis Mahkamah Konstitusi sangat dibutuhkan sebagai penyeimbang dan melakukan kontrol terhadap produk undang-undang yang dihasilkan oleh Presiden dan DPR untuk memastikan bahwa produk undang-undang tersebut tidak bertentangan dengan prinsip-prinsip konstitusi.

Pasal 21 UUD 1945 sesudah perubahan memberikan hak kepada anggota DPR untuk mengajukan usul rancangan undang-undang dan hak ini timbul dari adanya kewenangan DPR 
sebagai pemegang kekuasaan membentuk undang-undang sebagaimana ditegaskan Pasal 20 ayat (1) UUD 1945 sesudah perubahan. Kedudukan DPR sebagai lembaga perwakilan rakyat yang para anggotanya dipilih secara langsung oleh rakyat melalui pemilihan umum merefleksikan adanya mandat rakyat di dalam tugas dan kewajiban anggota DPR sebagai legislator untuk mewujudkan kehendak rakyat melalui undang-undang.

Hak anggota DPR untuk mengajukan usul rancangan undang-undang sebagaimana diatur dalam Pasal 21 UUD 1945, kurang begitu memberi kontribusi yang signifikan dalam mengimbangi hak inisiatif Presiden. Hal ini dikarenakan rancangan undang-undang yang diajukan anggota DPR tersebut baru sekedar usul dan bukan dalam arti rancangan undangundang yang utuh sebagaimana dipahami dalam hak inisiatif Presiden dalam Pasal 5 ayat (1) UUD 1945. Seharusnya apa yang diajukan oleh anggota DPR bukanlah "usul" rancangan undang-undang namun "rancangan" utuh sebagaimana halnya rancangan undang-undang yang berasal dari hak inisiatif Presiden berdasarkan pasal 5 ayat (1) UUD 1945.

Setelah usul rancangan undang-undang dari anggota DPR dibicarakan dan disetujui rapat paripurna DPR, rancangan tersebut selanjutnya dikirim kepada Presiden untuk dimintai pendapat sekaligus surat permintaan agar Presiden menunjuk Menteri yang akan mewakili Presiden dalam melakukan pembahasan rancangan tersebut bersama-sama DPR. Surat DPR tersebut pada prakteknya sering dimaknai sebagai permintaan pendapat persetujuan Presiden terhadap rancangan undang-undang yang dikirim DPR. Mekanisme sebagaimana diuraikan diatas menunjukkan bahwa campur tangan Presiden cukup besar dalam pembentukan undangundang. Surat balasan Presiden menunjukkan kontrol Presiden sudah dimulai sejak awal proses legislasi.

Ketentuan Pasal 21 UUD 1945 juga tidak jelas ketika tidak ada pengaturan secara tegas di dalam UUD 1945 mengenai mekanisme selanjutnya dari pengajuan usul rancangan undangundang oleh anggota DPR tersebut. Mekanisme lanjutan dari usul rancangan undang-undang yang diajukan anggota DPR hanya diatur dalam UU No. 12/2011. Usul dimaksud terlebih dahulu harus dibicarakan di internal DPR untuk kemudian disetujui sebagai rancangan undangundang dari DPR. Selanjutnya rancangan tersebut dibahas bersama-sama oleh DPR dan Presiden untuk mendapatkan persetujuan bersama. Melihat pengaturan dalam UU No. 12/2011 maka dapat dimengerti jika usul rancangan undang-undang dari anggota DPR mungkin saja tidak akan pernah menjadi rancangan undang-undang apabila tidak mendapat persetujuan dalam rapat paripurna DPR. Mekanisme lanjutan dalam UU No. 12 /2011 tersebut telah mereduksi makna kekuasaan legislasi DPR sebagaimana ditegaskan dalam Pasal 20 ayat (1) 
UUD 1945. Ketentuan undang-undang tersebut juga telah mempersempit ruang gerak anggota DPR untuk memperjuangkan aspirasi rakyat dalam proses legislasi.

Hak anggota DPR tersebut merupakan bagian penting dari rangkaian proses pembentukan undang-undang dimana DPR adalah pemegang kekuasaan membentuk undangundang. Seharusnya mekanisme lanjutan dari penggunaan hak anggota DPR untuk mengajukan usul rancangan undang-undang diatur dalam UUD 1945 dengan dasar pemahaman bahwa hak tersebut merupakan satu kesatuan proses legislasi dan refleksi penegasan DPR sebagai pemegang kekuasaan pembentukan undang-undang.

Pengaturan dalam undang-undang dasar dan bukan dalam peraturan setingkat undangundang tentang mekanisme lanjutan dari hak anggota DPR, mencerminkan adanya jaminan terhadap terwujudnya prinsip kedaulatan rakyat karena anggota DPR adalah representasi dari rakyat yang diwakilinya. Anggota DPR memiliki tanggung jawab profesional, politik dan moral untuk memperjuangkan lahirrnya undang-undang yang senafas dengan kehendak rakyat.

Ketentuan Pasal 21 UUD 1945 sesudah perubahan harus ditempatkan dalam bingkai makna pelaksanaan kedaulatan rakyat. Oleh karena itu, dengan kekuasaan yang dimilikinya maka anggota DPR sudah seharusnya berperan aktif dalam proses legislasi melalui hak konstitusionalnya mengajukan usul rancangan undang-undang. Segala hal yang menghalangi pelaksanaan fungsi legislasi DPR, hak anggota untuk mengajukan rancangan undang-undang dan mekanisme lanjutannya, sudah seharusnya diubah untuk kemudian disesuaikan dengan ketentuan Pasal 20 ayat (1) UUD 1945.

Selanjutnya, Pasal 20 ayat (2) UUD 1945 sesudah perubahan memberi kewenangan kepada eksekutif untuk terlibat dalam pembahasan dan memberi persetujuan terhadap rancangan undang-undang menjadi undang-undang. Keterlibatan eksekutif dalam proses pembahasan dan persetujuan rancangan undang-undang tersebut tidak sesuai dengan prinsip sistem pemerintahan presidensial. Pada sistem eksekutif nonparlementer (fixed executive) atau sistem presidensial sebagaimana yang dipraktekkan di Amerika Serikat, Presiden atau pemerintah tidak ikut serta dalam pembahasan dan persetujuan rancangan undang-undang yang pada dasarnya merupakan refleksi kedaulatan rakyat yang termanifestasi dalam sosok lembaga legislatif sebagai lembaga perwakilan rakyat yang diberi kekuasaan untuk membentuk hukum (undang-undang). Eksklusifitas kekuasaan legislasi yang dimiliki oleh lembaga legislatif sekaligus merupakan konsekuensi dari pemisahan secara tegas mengenai kedudukan dan fungsi cabang kekuasaan eksekutif dan legislatif dalam penyelenggaraan kekuasaan negara.

Demikian halnya dengan persetujuan rancangan undang-undang menjadi undangundang mutlak menjadi kewenangan DPR karena undang-undang merupakan representasi 
kehendak rakyat dalam bentuk peraturan hukum yang mengikat secara umum. Keharusan adanya persetujuan Presiden dalam tahap pembahasan menghambat proses terbentuknya undang-undang yang aspiratif oleh DPR. Apalagi jika rancangan undang-undang yang sedang dibahas ternyata tidak sejalan dengan kebijakan pemerintahan Presiden.

Kewenangan konstitusional Presiden yang cukup besar dalam proses legislasi sebagaimana tersimak dalam UUD 1945 sesudah perubahan juga tidak dapat diletakkan dalam konteks Presiden sebagai kepala negara sebagaimana yang dipahami dalam praktek sistem pemerintahan parlementer. Selain sebagai simbol pemersatu bangsa dan penjaga kesatuan negara, kedudukan kepala negara dalam kerangka sistem pemerintahan parlementer dimaksudkan untuk merawat keseimbangan antara pemerintah dan parlemen yang selalu diliputi ketegangan dan cenderung tidak stabil.

Pada sistem pemerintahan presidensial kedudukan Presiden sebagai kepala negara telah melebur dalam kedudukannya sebagai kepala pemerintahan. Peleburan itu diikuti dengan sejumlah pembatasan konstitusional untuk mencegah konsentrasi kekuasaan negara di tangan Presiden yang sangat berpotensi untuk disalahgunakan. Sistem presidensial menempatkan kekuasaan pembentukan undang-undang di tangan legislatif dan kekuasaan pemerintahan dipegang oleh eksekutif (Presiden). Pembatasan fungsi dan pemisahan secara tegas kedua cabang kekuasaan itu dimaksudkan untuk menciptakan keseimbangan hubungan eksekutif dan legislatif dalam penyelenggaraan sistem kekuasaan negara. Pembatasan dan pemisahan tersebut juga dimaksudkan untuk menghindari munculnya lembaga negara dengan kekuasaan yang sangat besar sehingga sulit dikontrol dan akhirnya berujung pada penyalahgunaan kekuasaan (abuse of power).

Hal ikhwal pembentukan undang-undang pascareformasi mestinya dibangun diatas kerangka sistem pemerintahan presidensial yang memisahkan secara tegas cabang kekuasaan eksekutif dan legislatif beserta fungsinya masing-masing. Eksistensi lembaga legislatif merupakan wujud implementasi gagasan pembatasan kekuasaan dan berfungsi sebagai institusi penyeimbang kekuasaan lembaga eksekutif. Jimly Asshiddiqe (2010: 221-224) menyatakan, dalam konsep pemisahan kekuasaan Presiden sebagai pihak eksekutif (pemerintah) hanya bertindak sebagai pelaksana undang-undang. Kalaupun pemerintah berwenang untuk menetapkan suatu peraturan perundang-undangan, maka kewenangan itu harus didasarkan atas pendelegasian kewenangan yang berasal dari pembentuk undang-undang (legislative delegation of the rule-making power). Dengan demikian berdasarkan UUD 1945 sesudah perubahan, DPR adalah satu-satunya lembaga pembentuk undang-undang dan Presiden merupakan pelaksana undang-undang. 
Konstruksi norma konstitusi yang mengatur tentang pembentukan undang-undang sebagaimana tersimak dalam UUD 1945 sesudah perubahan merefleksikan konsep pembagian fungsi atau difusi kekuasaan (diffusion of power) sebagai basis sistem parlementer. Menurut Bagir Manan (2006: 130), pembentukan undang-undang dalam pemahaman pembagian fungsi atau difusi kekuasaan ini mengakibatkan pembentukan undang-undang dilakukan bersamasama oleh eksekutif dan legislatif. Eksekutif ikut serta dalam pembahasan rancangan undangundang di badan perwakilan rakyat.

Pembentukan undang-undang seharusnya dimaknai sebagai satu kesatuan proses di bawah payung ketentuan Pasal 20 ayat (1) yang menegaskan bahwa DPR sebagai pemegang kekuasaan membentuk undang-undang. Pembentukan undang-undang merupakan otoritas mutlak DPR dalam kerangka sistem pemerintahan presidensial. Pasal 20 ayat (1) UUD 1945 sesudah perubahan dengan tegas menyatakan DPR memegang kekuasaan membentuk undangundang. Frasa "memegang kekuasaan” sebagaimana dirumuskan dalam Pasal 20 ayat (1) UUD 1945 sesudah perubahan harus dimaknai sebagai “memegang kewenangan”, karena suatu kekuasaan (macht) dalam hal ini kekuasaan membentuk undang-undang (wetgevende macht) mengandung makna kewenangan membentuk undang-undang. Karena kekuasaan membentuk undang-undang berada di tangan DPR maka pengajuan, pembahasan dan persetujuan rancangan undang-undang menjadi undang-undang semestinya menjadi kewenangan DPR.

Sudah menjadi kelaziman bahwa kekuasaan membentuk undang-undang berada di tangan lembaga legislatif sebagai perwujudan kedaulatan rakyat. Lembaga legislatif merupakan salah satu basis struktur bangunan demokrasi. Demokrasi dan kedaulatan rakyat akan kehilangan makna tanpa adanya lembaga legislatif. Oleh karena itu, kekuasaan membentuk undang-undang sudah semestinya menjadi kewenangan DPR sebagai lembaga perwakilan rakyat sebagai perwujudan kedaulatan rakyat. Lembaga legislatif bertugas menyalurkan, menerjemahkan dan mentransformasikan kehendak rakyat ke dalam kaidahkaidah normatif yakni, undang-undang. Sifat undang-undang yang berlaku umum, memaksa dan dilengkapi sanksi-sanksi, sudah pasti memiliki konsekuensi yang membebani rakyat. Prinsip negara demokrasi merefleksikan bahwa rakyat harus ikut serta dalam pembuatan aturan hukum yang akan membebani dirinya sendiri dan berdampak luas bagi kehidupannya seharihari. Proses pembuatan hukum dan produk yang dihasilkannya harus mampu memberi perlindungan bagi seluruh rakyat dan karena itu segala proses pembuatan hukum dan produk hukum harus merefleksikan kehendak rakyat.

Pembuatan dan penerapan hukum yang tidak linier dengan kehendak rakyat dan tanpa persetujuan rakyat sudah jelas mencederai prinsip demokrasi dan negara hukum. Lembaga 
legislatif merupakan penyangga utama yang memperkokoh struktur bangunan negara hukum. Lembaga legislatif merupakan jantung negara hukum. Bangunan negara hukum akan runtuh dan tidak memiliki arti apa-apa tanpa adanya lembaga legislatif. Lembaga legislatif juga menjabarkan amanat konstitusi dalam bentuk undang-undang sehingga menjadi dasar legalitas atau pedoman bagi setiap pejabat dan aparatur negara dalam menjalankan fungsi pemerintahan.

\section{KESIMPULAN}

\section{Simpulan}

Pengaturan kekuasaan legislasi Presiden sesudah perubahan UUD 1945 belum sesuai dengan prinsip sistem pemerintahan presidensial yang memisahkan secara tegas cabang kekuasaan eksekutif dan legislatif dalam sistem kekuasaan negara sebagai implementasi gagasan pembatasan kekuasaan dan prinsip kedaulatan rakyat. Kekuasaan legislasi Presiden sesudah perubahan UUD 1945 dapat melemahkan fungsi legislasi DPR, menciptakan ketidakseimbangan antara eksekutif dan legislatif, dan menghambat terwujudnya UndangUndang yang sesuai dengan kehendak rakyat.

\section{Rekomendasi}

Berdasarkan kesimpulan yang telah diutarakan diatas penulis mengajukan saran, antara lain:

1. Bagi Majelis Permusyawaratan Rakyat agar melakukan perubahan kembali terhadap Pasal 5 ayat (1) dan Pasal 20 ayat (2), (3), dan (4) UUD 1945. Perubahan tersebut diperlukan untuk menata kembali kedudukan eksekutif dan legislatif beserta fungsinya dalam pembentukan undang-undang dalam kerangka sistem pemerintahan presidensial. Kedudukan dan hubungan eksekutif dan legislatif dalam pembentukan undang-undang harus konsisten dengan prinsip sistem pemerintahan presidensial sebagai pilihan sistem pemerintahan negara Republik Indonesia pascareformasi. Konsistensi tersebut dimaksudkan untuk menghindari penumpukan kekuasaan negara di tangan Presiden, menciptakan keseimbangan kedudukan eksekutif dan legislatif dalam penyelenggaraan pemerintahan negara, memperkuat fungsi legislasi DPR dan menjamin terbentuknya undang-undang yang lebih aspiratif sebagai wujud pelaksanaan kedaulatan rakyat.

2. Bagi Dewan Perwakilan Rakyat agar melakukan pembenahan terhadap kinerja legislasi dan meningkatkan fungsi Badan Legislasi serta komponen lainnya yang terkait dengan sistem legislasi. Anggota DPR juga harus terus meningkatkan ilmu pengetahuan dan kemampuan dasar dalam hal perancangan undang-undang (legal drafting) agar lebih maksimal dalam 
mengawal suara rakyat pada proses pembentukan undang-undang. Dalam hal ini DPR dapat melibatkan kalangan perguruan tinggi yang memiliki kemampuan analisis dan sumberdaya pengetahuan yang lebih besar. Bagi anggota DPR juga diharapkan mampu menjunjung tinggi etika dan hukum dalam melaksanakan tugas-tugasnya sebagai legislator.

3. Bagi Pemerintah agar lebih mendorong peningkatan kualitas DPR dalam kinerja legislasi. Pemerintah juga diharapkan dapat meningkatkan anggaran dan menyediakan sumberdaya lainnya yang dapat mendukung DPR dalam pelaksanaan fungsi legislasinya.

4. Bagi kalangan perguruan tinggi agar lebih membangun koordinasi dan komunikasi yang baik dengan DPR. Dalam hal ini perguruan tinggi dapat menjadi mitra strategis bagi DPR untuk memperkuat muatan filosofis, sosiologis, dan yuridis dari produk legislasi. Perguruan tinggi seharusnya juga lebih dilibatkan secara optimal melalui kegiatan penelitian dan pengembangan untuk memperkuat dan meningkatkan peran DPR dalam perumusan kebijakan negara melalui pelaksanaan fungsi legislasi. Melalui sinergi dan kerjasama yang baik antara DPR dan perguruan tinggi juga diharapkan dapat mendorong pengembangan ilmu pengetahuan di perguruan tinggi, khususnya bidang ilmu hukum.

\section{DAFTAR RUJUKAN}

AR, Hanta Yuda. Presidensialisme Setengah Hati. Gramedia Pustaka Utama, 2013.

Asshiddiqie, Jimly, and Ketua Mahkamah Konstitusi RI. "Kedudukan Mahkamah Konstitusi Dalam Struktur Ketatanegaraan Indonesia." Makalah Kuliah Umum di Fakultas Hukum Universitas Sebelas Maret, Surakarta, Kamis 2 (2004).

Effendy, Marwan. Kejaksaan RI: Posisi Dan Fungsinya Dari Perspektif Hukum. Gramedia Pustaka Utama, 2005.

Isra, Saldi. Pergeseran Fungsi Legislasi: Menguatnya Model Legislasi Parlementer Dalam Sistem Presidensial Indonesia. RajaGrafindo Persada, 2010.

Jackson, Vicki C, and Mark Tushnet. "Comparative Constitutional Law: Cases and Materials," 1999.

Kartohadiprodjo, Sudiman. Pengantar Tata Hukum Di Indonesia: Hukum Perdata. Vol. 1. Pembangunan, 1963.

Kusumaatmadja, Mochtar, and Etty Roesmaryati Agoes. Pengantar Hukum Internasional. Pusat Studi Wawasan Nusantara, Hukum dan Pembangunan bekerjasama dengan Penerbut PT Alumni, 2003.

Manan, Bagir. Konvensi Ketatanegaraan. Fh Uii Press, 2006.

Marzuki, Mahmud. Penelitian Hukum: Edisi Revisi. Prenada Media, 2017.

Mertokusumo, Sudikno. "Penemuan Hukum Sebuah Pengantar." Yogyakarta: Liberty (1996). Siahaan, Maruarar. "Checks and Balances Dan Judicial Review Dalam Legislasi Di Indonesia." dalam http://www. jimlyschool. com/read/analisis/333/checks-and-balances-danjudicial-review-dalam-legislasi-di-indonesial, diunduh pada 12 (2012).

Siswayanti, Novita. "REVIEW BUKU: SYARAH KONSTITUSI UUD 1945 DALAM PERSPEKTIF ISLAM." HUNAFA: Jurnal Studia Islamika, 2013. http://jurnalhunafa.org/index.php/hunafa/article/view/37. 